\title{
Evaluation of mechanical behaviour of soil-lime mixtures under various exposure conditions
}

\author{
Marco Antônio de Moraes Alcântara and José Augusto de Lollo \\ University of São Paulo State, at Ilha Solteira - FEIS / UNESP \\ Av. Brasil Centro, Ilha Solteira - SP, Brazil
}

\begin{abstract}
This paper discusses the mechanical behaviour of soil-lime mixture under various exposure conditions. The study was carried out with three kinds of tropical soil (i.e., yellow-red latossol, dark red latossol, and yellow-red podzolic) collected from the northwest of the São Paulo State and southeast of the Mato Grosso do Sul State, in the Paraná River Sedimentary Basin, Brazil. The soil-lime mixtures were prepared in two compaction grades ( $95 \%$ and $100 \%$ of Proctor energy) with $8 \%$ of lime and tested under axial compression. The specimens were prepared in three different exposure conditions (i.e., fully immersed, partially immersed, and exposed in the air) and they were tested in three different time intervals (six, twelve, and eighteen months after compaction). The three soil types showed a very distinct mechanical behaviour in terms of their strength due to lime addition, exposure conditions, and maximum shearing resistance.
\end{abstract}

\section{INTRODUCTION}

Mixing of soil with lime enhances its mechanical properties such as plasticity, expansion, bearing capacity, and elasticity. Although this technique had its origin in cold climatic regions, it received a wide application in the tropical areas. In Brazil, Ferraz (1994), Oliveira et al. (1994), and Alcântara (1995) studied the properties of the soil-lime mixture. Most of these studies were carried out in the laboratory conditions. On the other hand, Alcântara et al. (1996) studied the soil-lime behaviour under various exposure conditions (i.e., fully immersed, partially immersed, and exposed in the air). The study found that the mechanical performance of the brick produced in manual press was more resistant than the specimen produced in the laboratory, even for the same exposure conditions.

In some cases, the mechanical resistance of the soil-lime mixture with longer cementing time was less than that of the soil with shorter cementing time. The decrease in mechanical resistance with time is opposite to the hypothesis that soil stiffening with lime guarantees resistance gain. On the other hand, a higher degree of compaction can restrain the process of cementation. Consequently, the specimen may not be strong enough to constrain microfracturing due to dry and wet cycles or thermal effects. Any chemical process can ultimately lead to the reduction of mechanical resistance of the soil-lime mixture. A longer (one year) duration of consolidation can faithfully represent the time period required for increased mechanical resistance (Alcântara et al. 1996) due to cementation in these soils or could be followed by new cycles of resistance gain due to lime diffusion, called "auto-regeneration" by Lima et al. (1993). It is also important to understand whether the durability of the soil-lime mixture is the same in varied circumstances or there is a relationship between the working conditions and the tropical climate.
In view of the above situation, the present study focuses on the rheological and chemical characteristics of the tropical soils from Ilha Solteira (São Paulo State, Brazil) under different exposure conditions and cementing time interval. The main objectives of this study were: (1) to characterise the resistance gain effect of soil-lime mixture in terms of cementing time; (2) to evaluate this resistance gain for different tropical soil types of the Ilha Solteira region under different exposure conditions; and (3) to understand the chemical processes influencing the resistance.

\section{Soil samples}

The three soil types were yellow-red latossol (YrL), yellow-red podzolic (YrP), and dark-red latossol (DrL). The main chemical characteristics of these soils (Table 1): organic matter (OM), cation exchange capacity, and aluminium exchange $(\mathrm{Al})$ were obtained from the techniques proposed by De Fellipo and Ribeiro (1981). Free iron oxide $\left(\mathrm{Fe}_{2} \mathrm{O}_{3}\right)$ was analysed by applying the Cicrate-Ditionite technique (Coffin 1963) and $\mathrm{pH}$ index was obtained from the soil-water mixture with a platinum electrode.

The specimens were prepared under two degrees of compaction (i.e., $95 \%$ - more practical working situation and $100 \%$ - ideal conditions) with $8 \%$ of lime by weight, and moulded in a Mini-CBR cylinder with normal Proctor energy. The specimens were moulded in duplicate for each case (i.e., soil type, compaction degree, exposure condition, and cementing time).

Three exposure conditions were considered for the specimens: fully immersed, partially immersed, and exposed in the air (representing respectively the soil mass below the groundwater table, at the water table, and above the water table). In order to evaluate the mechanical resistance evolution of these specimens, we used three different cementing (curing) times: six, twelve, and eighteen months. 


\section{Axial compression test}

After the cementing time, the above specimens underwent axial compression. The test was carried out with the soil

Table 1: Chemical characteristics of soil

\begin{tabular}{|c|c|c|c|c|c|}
\hline Soil type & $\mathbf{p H}$ & $\begin{array}{c}\text { Cation exchange } \\
\text { capacity } \\
(\mathrm{meq} / 100 \mathrm{~g})\end{array}$ & $\begin{array}{c}\text { Aluminium } \\
\text { exchange } \\
\left(\mathbf{C m o l c} / \mathrm{dm}^{3}\right)\end{array}$ & $\begin{array}{c}\text { Organic } \\
\text { matter } \\
(\mathrm{dag} / \mathrm{kg})\end{array}$ & $\begin{array}{c}\mathrm{Fe}_{2} \mathrm{O}_{3} \\
(\%)\end{array}$ \\
\hline $\begin{array}{c}\text { Dark- red } \\
\text { Latossol } \\
\text { (DrL) }\end{array}$ & 4.6 & 4.1 & 0.4 & 1.2 & 13.9 \\
\hline $\begin{array}{c}\text { Yellow-red } \\
\text { Podzolic } \\
(\mathrm{YrP})\end{array}$ & 5.3 & 4.8 & 0.0 & 0.4 & 5.2 \\
\hline $\begin{array}{c}\text { Yellow-red } \\
\text { Latossol } \\
(\mathrm{YrL})\end{array}$ & 4.0 & 3.3 & 0.5 & 0.5 & 4.1 \\
\hline
\end{tabular}

Table 2: Mechanical characteristics of yellow-red podzolic soil

\begin{tabular}{|c|c|c|c|c|c|}
\hline $\begin{array}{l}\text { Soil } \\
\text { type }\end{array}$ & $\begin{array}{l}\text { Exposure } \\
\text { condition }\end{array}$ & $\begin{array}{c}\text { Cementing } \\
\text { time } \\
\text { (months) }\end{array}$ & $\begin{array}{c}\text { Degeree of } \\
\text { compaction } \\
(\%)\end{array}$ & $\begin{array}{l}\text { Axial c } \\
\text { streng }\end{array}$ & $\begin{array}{l}\text { essive } \\
\left./ \mathrm{cm}^{2}\right)\end{array}$ \\
\hline \multirow{18}{*}{ 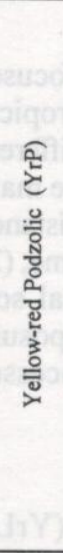 } & \multirow{6}{*}{ 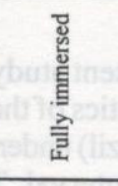 } & \multirow{2}{*}{6} & 95 & 13.11 & 13.12 \\
\hline & & & 100 & 17.41 & 18.81 \\
\hline & & \multirow{2}{*}{12} & 95 & 22.04 & 21.34 \\
\hline & & & 100 & 25.80 & 25.78 \\
\hline & & \multirow{2}{*}{18} & 95 & 19.46 & 21.61 \\
\hline & & & 100 & 25.16 & 26.76 \\
\hline & \multirow{6}{*}{ 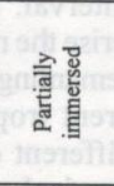 } & \multirow{2}{*}{6} & 95 & 13.97 & 13.95 \\
\hline & & & 100 & 13.76 & 12.90 \\
\hline & & \multirow{2}{*}{12} & 95 & 15.05 & 17.20 \\
\hline & & & 100 & 12.47 & 19.24 \\
\hline & & \multirow{2}{*}{18} & 95 & 22.47 & 24.51 \\
\hline & & & 100 & 30.21 & 29.13 \\
\hline & \multirow{6}{*}{ 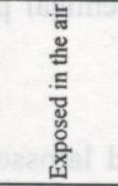 } & \multirow{2}{*}{6} & 95 & 20.96 & 19.35 \\
\hline & & & 100 & 17.41 & 19.20 \\
\hline & & \multirow{2}{*}{12} & 95 & 30.85 & 26.12 \\
\hline & & & 100 & 28.92 & 29.45 \\
\hline & & \multirow[t]{2}{*}{18} & 95 & 17.74 & 18.06 \\
\hline & & & 100 & 20.64 & 21.50 \\
\hline
\end{tabular}

Table 3: Mechanical characteristics of yellow-red latossol

\begin{tabular}{|c|c|c|c|c|c|}
\hline $\begin{array}{l}\text { Soil } \\
\text { type }\end{array}$ & $\begin{array}{l}\text { Exposure } \\
\text { condition }\end{array}$ & $\begin{array}{c}\text { Cementing } \\
\text { time } \\
\text { (months) }\end{array}$ & $\begin{array}{c}\text { Degeree of } \\
\text { compaction } \\
(\%)\end{array}$ & \multicolumn{2}{|c|}{$\begin{array}{l}\text { Axial compressive } \\
\text { strength }\left(\mathbf{k g} / \mathrm{cm}^{2}\right)\end{array}$} \\
\hline \multirow{18}{*}{ 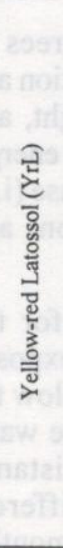 } & \multirow{6}{*}{ 芯号 } & \multirow{2}{*}{6} & 95 & 5.91 & 6.02 \\
\hline & & & 100 & 7.63 & 7.09 \\
\hline & & \multirow{2}{*}{12} & 95 & 8.28 & 8.92 \\
\hline & & & 100 & 9.14 & 9.34 \\
\hline & & \multirow{2}{*}{18} & 95 & 8.06 & 9.13 \\
\hline & & & 100 & 10.96 & 10.75 \\
\hline & \multirow{6}{*}{ 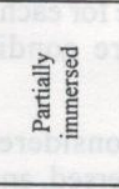 } & \multirow{2}{*}{6} & 95 & 5.70 & 6.24 \\
\hline & & & 100 & 6.77 & 6.88 \\
\hline & & \multirow{2}{*}{12} & 95 & 9.14 & 9.56 \\
\hline & & & 100 & 15.59 & 11.83 \\
\hline & & \multirow{2}{*}{18} & 95 & 10.32 & 11.50 \\
\hline & & & 100 & 13.87 & 12.90 \\
\hline & \multirow{6}{*}{ 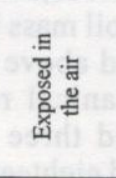 } & \multirow{2}{*}{6} & 95 & 13.12 & 13.33 \\
\hline & & & 100 & 12.80 & 10.97 \\
\hline & & \multirow{2}{*}{12} & 95 & 30.05 & 33.09 \\
\hline & & & 100 & 37.63 & 34.41 \\
\hline & & \multirow{2}{*}{18} & 95 & 24.94 & 23.76 \\
\hline & & & 100 & 39.56 & 40.42 \\
\hline
\end{tabular}

samples having the following variables: soil type (S), exposure condition (EC), cementing time (CT), degree of compaction (CD), and axial compression strength (TR). The results of the axial compression test are presented in Tables 2,3 , and 4 .

\section{Chemical analysis}

The main objective of the chemical analysis was to evaluate the influence of chemical environmental conditions in the reactions involving soil-lime cementation. The samples after the axial compression test were crushed and examined for $\mathrm{pH}$ and Redox potential. The analysis was done by applying the Patrick and Gambrell (1996) technique with a platinum sensitive electrode and an $\mathrm{Ag} / \mathrm{AgCl}$ reference electrode. The results are presented in Tables 5 , 6 , and 7 .

Table 4: Mechanical characteristics for dark-red latossol

\begin{tabular}{|c|c|c|c|c|c|}
\hline $\begin{array}{l}\text { Soil } \\
\text { type }\end{array}$ & $\begin{array}{l}\text { Exposure } \\
\text { condition }\end{array}$ & $\begin{array}{c}\text { Cementing } \\
\text { time } \\
\text { (months) }\end{array}$ & $\begin{array}{c}\text { Degree of } \\
\text { compaction } \\
(\%)\end{array}$ & \multicolumn{2}{|c|}{$\begin{array}{l}\text { Axial compressive } \\
\text { strength }\left(\mathrm{kg} / \mathrm{cm}^{2}\right)\end{array}$} \\
\hline \multirow{18}{*}{ 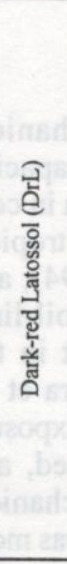 } & \multirow{6}{*}{ 合总 } & \multirow{2}{*}{6} & 95 & 0.54 & 0.43 \\
\hline & & & 100 & 2.00 & 2.12 \\
\hline & & \multirow{2}{*}{12} & 95 & 0.75 & 0.54 \\
\hline & & & 100 & 1.51 & 1.83 \\
\hline & & \multirow{2}{*}{18} & 95 & 0.53 & 0.64 \\
\hline & & & 100 & 1.61 & 1.82 \\
\hline & \multirow{6}{*}{ 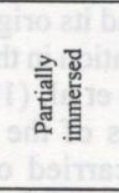 } & \multirow{2}{*}{6} & 95 & 1.40 & 1.72 \\
\hline & & & 100 & 1.94 & 2.26 \\
\hline & & \multirow{2}{*}{12} & 95 & 1.72 & 1.84 \\
\hline & & & 100 & 1.08 & 1.15 \\
\hline & & \multirow{2}{*}{18} & 95 & 0.96 & 0.63 \\
\hline & & & 100 & 1.72 & 2.36 \\
\hline & \multirow{6}{*}{ 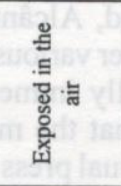 } & \multirow[t]{2}{*}{6} & 95 & 2.16 & 2.26 \\
\hline & & & 100 & 3.33 & 3.34 \\
\hline & & \multirow{2}{*}{12} & 95 & 3.33 & 2.37 \\
\hline & & & 100 & 3.31 & 3.23 \\
\hline & & \multirow{2}{*}{18} & 95 & 0.96 & 1.29 \\
\hline & & & 100 & 2.36 & 3.01 \\
\hline
\end{tabular}

Table 5: Chemical characteristics for yellow-red podzolic soil

\begin{tabular}{|c|c|c|c|c|c|}
\hline $\begin{array}{l}\text { Soil } \\
\text { type }\end{array}$ & $\begin{array}{l}\text { Exposure } \\
\text { condition }\end{array}$ & $\begin{array}{c}\text { Cementing } \\
\text { time } \\
\text { (months) }\end{array}$ & $\begin{array}{c}\text { Degeree of } \\
\text { compaction } \\
(\%)\end{array}$ & pH & $\begin{array}{c}\text { Redox } \\
\text { potential } \\
\text { (millivolts) }\end{array}$ \\
\hline \multirow{18}{*}{ 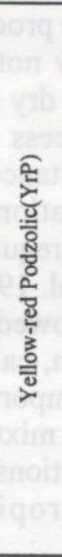 } & \multirow{6}{*}{ 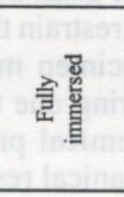 } & \multirow{2}{*}{6} & 95 & 11.1 & 29.1 \\
\hline & & & 100 & 11.0 & 28.3 \\
\hline & & \multirow{2}{*}{12} & 95 & 10.1 & -29.5 \\
\hline & & & 100 & 9.7 & 41.7 \\
\hline & & \multirow{2}{*}{18} & 95 & 10.2 & 6.8 \\
\hline & & & 100 & 10.2 & 48.1 \\
\hline & \multirow{6}{*}{ 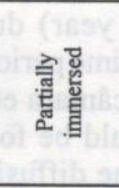 } & \multirow{2}{*}{6} & 95 & 11.2 & 21.6 \\
\hline & & & 100 & 11.5 & 16.2 \\
\hline & & \multirow{2}{*}{12} & 95 & 9.8 & 47.8 \\
\hline & & & 100 & 9.7 & 42.1 \\
\hline & & \multirow{2}{*}{18} & 95 & 10.2 & 25.1 \\
\hline & & & 100 & 10.3 & 31.2 \\
\hline & \multirow{6}{*}{ 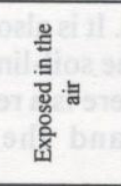 } & \multirow[t]{2}{*}{6} & 95 & 11.2 & 45.0 \\
\hline & & & 100 & 11.2 & 30.2 \\
\hline & & \multirow{2}{*}{12} & 95 & 10.0 & -60.6 \\
\hline & & & 100 & 9.7 & 68.0 \\
\hline & & \multirow{2}{*}{18} & 95 & 9.4 & 50.8 \\
\hline & & & 100 & 10.2 & 20.9 \\
\hline
\end{tabular}


Table 6: Chemical characteristics of yellow-red latossol

\begin{tabular}{|c|c|c|c|c|c|}
\hline $\begin{array}{l}\text { Soil } \\
\text { type }\end{array}$ & $\begin{array}{l}\text { Exposure } \\
\text { condition }\end{array}$ & $\begin{array}{c}\text { Cementing } \\
\text { time } \\
\text { (months) }\end{array}$ & $\begin{array}{c}\text { Degeree of } \\
\text { compaction } \\
(\%)\end{array}$ & pH & $\begin{array}{c}\begin{array}{c}\text { Redox } \\
\text { potential } \\
\text { (millivolts) }\end{array} \\
\end{array}$ \\
\hline \multirow{18}{*}{ 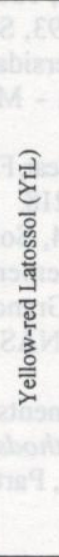 } & \multirow{6}{*}{ 君总 } & \multirow{2}{*}{6} & 95 & 11.8 & 18.2 \\
\hline & & & 100 & 11.8 & -11.1 \\
\hline & & \multirow{2}{*}{12} & 95 & 9.8 & -36.0 \\
\hline & & & 100 & 10.0 & -145.0 \\
\hline & & \multirow{2}{*}{18} & 95 & 10.1 & 15.0 \\
\hline & & & 100 & 8.9 & 16.8 \\
\hline & \multirow{6}{*}{ 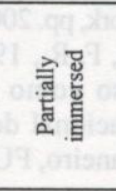 } & \multirow{2}{*}{6} & 95 & 12.0 & -14.9 \\
\hline & & & 100 & 11.8 & -29.1 \\
\hline & & \multirow{2}{*}{12} & 95 & 9.7 & 4.8 \\
\hline & & & 100 & 9.8 & -68.7 \\
\hline & & \multirow{2}{*}{18} & 95 & 10.1 & 14.8 \\
\hline & & & 100 & 9.9 & 16.6 \\
\hline & \multirow{6}{*}{ 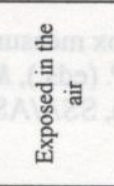 } & \multirow{2}{*}{6} & 95 & 12.2 & -25.5 \\
\hline & & & 100 & 12.2 & -17.5 \\
\hline & & \multirow{2}{*}{12} & 95 & 8.9 & 64.2 \\
\hline & & & 100 & 9.5 & 2.4 \\
\hline & & \multirow{2}{*}{18} & 95 & 9.8 & 21.0 \\
\hline & & & 100 & 10.0 & -3.5 \\
\hline
\end{tabular}

\section{CONCLUSIONS AND DISCUSSIONS}

The effect of resistance loss with time seems to be a general rule for the studied soils without interference of any other factor. Soil chemical composition, especially $\mathrm{Fe}_{2} \mathrm{O}_{3}$ and organic matter concentrations, seem to be the main factors controlling the soil-lime reactions. But consolidation time and environmental conditions also are the other significant factors. The Redox Potential apparently doesn't have an important effect in soil-lime reactions as well as resistance gain with time for the considered soils. Exposure conditions play an important role in soil-lime cementation, mainly for immersed and partially immersed conditions.

\section{Resistance gain}

The results indicate that the YrP soil has better axial resistance evolution in the different exposure conditions considered. This soil shows good resistance evolution but has the resistance reduction with time. This behaviour was previously verified and asserted to less compaction degree obtained for these soils.

With increasing cementing time, the YrL showed a small resistance gain in fully immersed and partially immersed conditions and a good resistance evolution for the specimens exposed in the air. The significant resistance gain by the soil samples exposed in the air can be attributed to their least $\mathrm{Fe}_{2} \mathrm{O}_{3}$ content in comparison with other types of soil. On the other hand, the poor results for fully immersed and partially immersed conditions could be explained by lime migration to specimen surface. A crust of lime in these specimens and lime and organic matter concentrations in the water indicated the migration.

For the DrL, the resistance evolution was less expressive in any considered conditions. For this soil type, the lower resistance value could be attributed to the high $\mathrm{Fe}_{2} \mathrm{O}_{3}$ and organic matter content, which could have attracted the negative charge particles of soil constraining the reactions between the soil particles and the lime.
Table 7: Chemical characteristics of dark-red latossol

\begin{tabular}{|c|c|c|c|c|c|}
\hline $\begin{array}{l}\text { Soil } \\
\text { type }\end{array}$ & $\begin{array}{l}\text { Exposure } \\
\text { condition }\end{array}$ & $\begin{array}{c}\text { Cementing } \\
\text { time } \\
\text { (months) }\end{array}$ & $\begin{array}{c}\text { Degeree of } \\
\text { compaction } \\
(\%)\end{array}$ & pH & $\begin{array}{c}\text { Redox } \\
\text { potential } \\
\text { (millivolts) }\end{array}$ \\
\hline \multirow{18}{*}{ 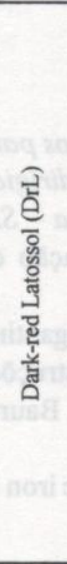 } & \multirow{6}{*}{ 总 } & \multirow{2}{*}{ 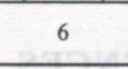 } & 95 & 11.1 & 0.0 \\
\hline & & & 100 & 11.9 & 0.2 \\
\hline & & \multirow{2}{*}{12} & 95 & 9.5 & -196.8 \\
\hline & & & 100 & 9.8 & -346.9 \\
\hline & & \multirow{2}{*}{18} & 95 & 8.7 & 45.4 \\
\hline & & & 100 & 9.9 & 15.9 \\
\hline & \multirow{6}{*}{ 苨 } & \multirow{2}{*}{6} & 95 & 12.0 & -28.6 \\
\hline & & & 100 & 11.5 & 64.1 \\
\hline & & \multirow{2}{*}{12} & 95 & 9.6 & -68.0 \\
\hline & & & 100 & 10.0 & -20.0 \\
\hline & & \multirow{2}{*}{18} & 95 & 8.7 & 90.2 \\
\hline & & & 100 & 8.8 & 92.2 \\
\hline & \multirow{6}{*}{ 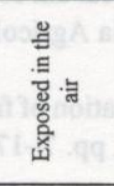 } & \multirow{2}{*}{6} & 95 & 12.2 & -42.1 \\
\hline & & & 100 & 11.8 & -37.6 \\
\hline & & \multirow{2}{*}{12} & 95 & 8.6 & -199.1 \\
\hline & & & 100 & 10.2 & -29.7 \\
\hline & & \multirow{2}{*}{18} & 95 & 8.6 & 19.0 \\
\hline & & & 100 & 9.7 & 9.7 \\
\hline
\end{tabular}

\section{Degree of compaction}

The process of "mechanical resistance loss in time" was originally observed in the YrP soil by Alcântara et al. (1996), and in that case, $C D$ was considered to be the main responsible factor for this process. But this process was not observed in the other soils. On the contrary, with increasing $\mathrm{EC}$, the YrP soil and DrL showed some increase in mechanical resistance. However, the actual results do not permit to assign the association between degree of compaction and resistance loss.

\section{Exposure conditions}

Generally, immersed and partially immersed conditions tend to present better results in resistance gain with time. But these processes are very slow and show that the hard water content while induced the lime-soil reactions could need a more long time of consolidation in order to present better results. In some situation the hard water content in the environment could cause the lime migration with resistance losses.

\section{Regeneration factor}

This effect was observed only in case of long cementing time. It is characterised by a initial decrease in resistance followed by an increase in resistance due to the internal rearrangement of lime.

\section{Chemical environment conditions factor}

The Redox Potential results obtained do not show any clear relationship between the chemical property and the mechanical behaviour of the soil-lime mixture. An interesting aspect was the concentration of negative values of Redox Potential for the YrL and DrL, which could be related to more $\mathrm{Fe}_{2} \mathrm{O}_{3}$ and organic matter content in these soils.

In this case, the organic matter could have undergone oxidation by $\mathrm{Fe}_{2} \mathrm{O}_{3}$ and the iron could have attracted the electrons (Merkle 1955). If this consideration is valid for these mixtures, then $\mathrm{Fe}_{2} \mathrm{O}_{3}$ and organic matter could inhibit the soil-lime reactions, leading to the resistance loss with time. 
On the other hand, $\mathrm{pH}$ values show very small variation, without any tendency to other related effects. The values may indicate that soil composition is the main factor responsible for $\mathrm{pH}$ results.

\section{REFERENCES}

Alcântara, M. A. M., 1995, Estabilização química de solos para fins rodoviários: técnicas disponiveis e estudo de caso dirigido à estabilização solo-cal de três solos de Ilha Solteira - SP. Universidade Federal de Viçosa, Viçosa, (Dissertação de Mestrado), $91 \mathrm{p}$.

Alcântara, M. A. M., Silva, S. A. M., Aguillar, F. D., and Segantini, A. A. S., 1996, Estabilização de solos com cal em construções rurais. Congresso Brasileiro de Engenharia Agrícola, Bauru. Anais. SBEA, 25, pp. 98-107.

Coffin, D. E., 1963, A method for the determination of free iron in soils and clays. Can. Jour. Soil Sci., v. 43, pp. 7-17.
De Fellipo, B. V. and Ribeiro, A. C., 1981, Análise química do solo. Universidade Federal de Viçosa, Viçosa, 17 p.

Ferraz, R. L., 1994, Contribuição ao estudo de estabilização de solos para fins rodoviários e habitacionais. Universidade Federal de Viçosa, Viçosa, (Dissertação de Mestrado), 180 p.

Lima, D. C., ROHM, S. A., and BARBOSA, P. S. A., 1993, Soil stabilization III - soil-lime to road application. Universidade Federal de Viçosa, Imprensa Universitária, Vicosa - MG, v. 334 , Sp. Publ., 46 p.

Merkle, F. G., 1955, Oxidation-reduction processes in soils. In: Bear, F. E. (ed.), Chemistry of the soils. Reinhold, New York, pp. 200-218.

Oliveira, P. J. R., Salles, F. M., and Andriolo, F. R., 1994, Soloaglomerante - disponibilidade para uso como elemento estrutural em barramentos. Seminário Nacional de Grandes Barragens, Anais. Rio de Janeiro, Rio de Janeiro, FURNAS, v. 1(21), pp. 197-208.

Patrick, W. H. and Gambrell, R. P., 1996, Redox measurements of soils. In: Patrick, W. H. and Gambrell, R. P. (eds.), Methods of soil analysis, Chemical Methods. Madison, SSA/ASA, Part 3, pp. 1255-1273. 